\title{
The Nexus between Financial Development and Economic Growth in China
}

\section{Voon Cheng-Sze, Rossazana Ab-Rahim \& Fouzi Salih Farag}

To Link this Article: http://dx.doi.org/10.6007/IJARBSS/v11-i5/9863

DOI:10.6007/IJARBSS/v11-i5/9863

Received: 05 March 2021, Revised: 09 April 2021, Accepted: 30 April 2021

Published Online: 10 May 2021

In-Text Citation: (Cheng-Sze et al., 2021)

To Cite this Article: Cheng-Sze, V., Ab-Rahim, R., \& Farag, F. S. (2021). The Nexus between Financial Development and Economic Growth in China. International Journal of Academic Research in Business and Social Sciences, 11(5), 89-99.

Copyright: ( 2021 The Author(s)

Published by Human Resource Management Academic Research Society (www.hrmars.com)

This article is published under the Creative Commons Attribution (CC BY 4.0) license. Anyone may reproduce, distribute, translate and create derivative works of this article (for both commercial and non-commercial purposes), subject to full attribution to the original publication and authors. The full terms of this license may be seen at: http://creativecommons.org/licences/by/4.0/legalcode

Vol. 11, No. 5, 2021, Pg. 89 - 99

Full Terms \& Conditions of access and use can be found at http://hrmars.com/index.php/pages/detail/publication-ethics 


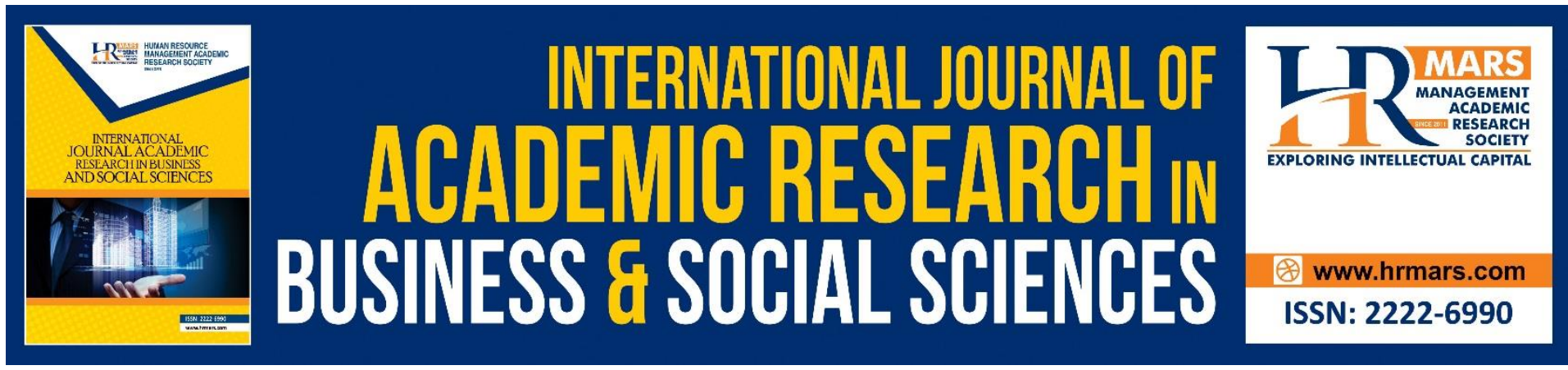

\title{
The Nexus between Financial Development and Economic Growth in China
}

\author{
Voon Cheng-Sze, Rossazana Ab-Rahim \& Fouzi Salih Farag \\ Universiti Malaysia Sarawak, Sarawak, Malaysia, Benghazi University, Benghazi, Libya \\ Email: rossazana@gmail.com
}

\begin{abstract}
The relationship between financial development and economic growth has been subject to the considerable debate in the literature of development and growth. Hence, this study aims to investigate the long-run relationship between financial development and economic growth of China over the period 1988 to 2018. This study employed Johansen's Cointegration and Granger Causality analysis to achieve the objectives of the study. The findings of this study indicate there is a long-run relationship between financial development and economic growth in China.
\end{abstract}

Keywords: Financial Development, Economic Growth, China

\section{Introduction}

Financial development is part of the development policy of the private sector to improve economic growth and reduce poverty by reducing the risks of the financial system and the cycle of increasing data acquisition costs, agreement compliance, and deal completion resulted in financial agreements, intermediaries, and industries developing (Eryılmaz, Bakir \& Mercan, 2015). In the time of crisis, the financial system distorts the allocation of funds, while stumbled economic growth and financial complexity is insufficient (Shaw, 1973).

Financial sector success can be measured based on the effects of financial stability on economic growth and poverty reduction (World Bank, 2019). Realistically, financial performances are hard to measure due to broad concept with several dimensions and a wide range of countries that are long-term accessible. However, the impact of financial sector in economic development are hard to denied especially in developing country (Shahbaz et al., 2013).

Financial development playing role as financial securities, financial markets and capital intermediaries are reduced by offering financial functions without necessarily eliminating the information gathering costs, contract execution costs and transaction costs (Levine, 2004). Moreover, Financial development reducing the risks of the financial system and the cycle of increasing data acquisition costs, agreement compliance, and deal completion resulted in financial agreements, intermediaries, and industries developing (Eryılmaz et al., 2015). Asteriou and Spanos (2019) suggested financial development promoted economic growth while adversely affecting economic activity in times of crisis. 
Banking sector has noteworthy role in economic growth by focusing on profitable projects, foster innovation, and creativity (Schumpeter, 1912). On other side of coin, financial system could jeopardize economic growth by increasing investment and risk levels and inefficient allocation of resources (Levine, 2004).

China, as the largest emerging market and the second largest economy has experienced phenomenal economic growth and development, now known as one of the world's largest economies. Since 1978, China has initiated an economic reform and has experienced enormous changes, several companies have been set up during that time, and local governments have acquired more control and resource distribution powers (Naughton, 2007; Yueh, 2013). On the one side, China's financial system was highly regulated by the government.

Although there are numerous studies on the relationship of financial development and economic for developed countries, notably the relationship remains highly contentious and subject to debate for developing countries particularly in third world countries. The objective of this study is to investigate the long-run relationship between financial development and economic growth in China and to examine the causality relationship between financial development and economic growth in China. The next section provides the theoretical rationale with empirical evidence on the economic growth and financial development and the section on data and methods follows on economic growth. Empirical results will be discussed in the next section, and finally on the conclusion and future direction of the research study.

\section{Literature Review}

There are two theory of economic growth: endogenous growth theory and the exogenous growth theory. Based on Arrow and Hurwicz (1962) endogenous growth model focuses on a knowledge-based economy's positive externalities and spillover effects ultimately lead to economic development. Moreover, endogenous growth hypothesis explains that economic growth driven by human capital, technology, and knowledge greatly leads to economic growth by means of transparency, rivalry and creativity policies and support by government (Eryılmaz et al., 2015; Howitt \& Aghion, 1998). However, theory of neoclassical exogenous growth has adopted the basic neoclassical framework of long-term economic growth which is known as Solow-Swan growth model (Solow, 1956). The main 4 indication elements of neoclassic growth model are productivity, capital accumulation, growth of population and technological advancement (Gokal \& Hanif, 2004). Moreover, technologies innovation has significantly known as a counterbalance for decreasing return of capital accumulation (Howitt \& Aghion, 1998).

Development of financial services plays an enormous role to stimulate the economy especially through growing the interest rate, investment mobilization and pooling, delivery of information on capital, promoting and attracting foreign capital inflows, and maximizing capital allocation (World Bank, 2019). On another word, financial stability is contributing to the economic growth. According to Asteriou and Spanos (2019) financial stability are significantly contribute to economic growth before crisis and diminishing during recovery period. Eryılmaz et al. (2015) explains better performing financial system driven economic growth and economic production. In the case of Nepal, there is a long run correlation between GDP, large cash (M2) and private sector domestic credit (Dhungana, 2016). Based on Lenka (2015) financial improvement has one-way causality towards economic growth. However, there are several studies shows bi-direction between economic growth and financial development (Calderon \& Liu, 2003; Karlsson \& Mansson, 2015; Kyophilavong et al., 2016). 
According to Lucchetti et al. (2001) banks' effectiveness has positive influences economic growth. This finding is in line with Baier et al. (2003) that stock exchange improves production growth and productivity growth. Poor regulatory and policy financial development can hinder economic development, therefore financial development serves as alternative of investment volume (De Gregorio \& Guidotti, 1995).

\section{Methodology}

The study utilizes secondary data over the period of 1988 to 2018 obtained from the World Bank Group. Financial development as an independent variable. Three indicators of financial development are used to track financial services access: the proxy variables include private-sector bank credit, financial-sector domestic credit (\% of GDP) and broad money growth (\% of annual growth). The GDP growth rate (GDPG) are used as the proxy of economic growth. Moreover, government spending percent of GDP (EXP1), the rate of inflation measured by consumer price index (INF), and population growth rate (POP) are used as a control variable. The variables are adopted from Prochniak and Wasiak (2017) and Olowofeso et al. (2015). To measure the relationship between financial development and economic growth a long-term time series data, this study has used several methodologies unit root test, Johansen co-integration test, and Granger Causality used to achieve the objective of this study. Economic growth serves as the dependent variable, financial development, and control variables as an independent variable.

H1: There is a long-run relationship between financial development and economic growth.

The hypothesis explains to raise investment levels and efficient accumulation of capital financial services works efficiency allocation resources and expansion of credit across. At the developed countries correlation between credit market and economic growth are noticeable due to the matured credit market. Moreover, the credit from the private sector promotes growth by increasing investment and adaption of new technologies. However, developing and emerging countries, the channel of capital accumulation is mainly significant compare to productivity. Based on Mishkin (2007) a better functioning credit system would reduce the existing funding restrictions that hinder credit expansion, and the expansion of businesses and sectors, as a results financial development would increase economic growth.

H2: There is a causality relationship between financial development and economic growth.

According to Al Mamun et al. (2018), domestic credit is channeled through a financial distribution system used domestic credit at various range and has different types of interest rates to the real market, these rates affect commercial banks ' lending and investing interest rates. Theoretically, lending rate have significant impact on size of domestic credit in an economy, thus economic growth has a negative impact (Mallick \& Agarwal, 2007).

\section{Unit Root Tests}

A sequence of vectors chosen is called stationary if it has a constant; the unit root check is a statistical tool used to evaluate whether the variables under the autoregressive model are stationary or non-stationary. Unit root test used to test whether the independent variables of financial development that peroxided by bank credit to the private sector, domestic credit provided by the financial sector (\% of GDP), and broad money growth (annual $\%)$. 
The Augmented Dickey-fuller (ADF) test used to evaluate the stationary of a sequence of the collective element root tests. A Dickey-Fuller test is a root unit analysis which measures in the following design formula the null hypothesis that $\hat{I} \pm=1$. Alpha is the coefficient of the first lag on Y. It basically has a null hypothesis like that of the unit root test. That is, the $\mathrm{Y}(\mathrm{t}-1)$ coefficient is 1 , which implies the presence of a root unit. If not discarded, the sequence will be considered non-stationary.

$\mathrm{H}_{0}$ : There is a unit root for the series, the series is stationary.

$\mathbf{H}_{\mathrm{a}}$ : There is no unit root for the series, the series is non-stationary.

If ADF statistics exceed critical value, the $\mathrm{HO}$ can be rejected. Hence the $\mathrm{H} 1$ is accepted which means the data are stationary.

\section{Co-integration Test}

Johansen method is used in order to determine the number of co-integrating vectors; it provides two different likelihood ratio tests, the trace test and the maximum eigenvalue test The Johansen co-integration test is based on Vector autoregressive model (VAR). The decision criteria is to reject $\mathrm{HO}$ if the Maximum Eigenvalue and Trace values are greater than the tabulated $5 \%$ critical value.

There may be more than one co-integration relationship for a system of more than two non-stationary series. Then the variables can involve short-term and long-term relationships. A more general approach is therefore required. In order to solve this problem, (Johansen, $1988,1991)$ suggests two likelihood ratio related co-integration measures, namely the trace test and the maximum eigenvalue test.

Suppose a pth order vector autoregressive model (VAR(p)):

$$
x_{t}=\eta_{0}+\eta_{1 t}+\Gamma_{1} x_{t-1}+\ldots+\Gamma_{p} x_{t-p}+\varepsilon_{1}(t=p+1, \ldots, T)
$$

where $x t$ is an $m$-dimensional vector and is integrated of order one; $\eta 0$ and $\eta 1$ are $m$ by 1 vector of constants; $\Gamma_{1} \ldots \Gamma_{p}$ are $m$ by $m$ parameter matrices and $\varepsilon t$ is $m$-dimensional independent and identical Gaussian distribution. Johansen test is based on a vector error correction model (VECM), which can be derived from the above VAR model. First, subtract xt1 from both sides of the equation; then replace $x_{t-i}$ by $\Delta x_{t-1}+x_{t-i+-1}$ for all $i=1,2, \ldots, p-1$.

The trace test statistics is $\operatorname{LR}_{\text {trace }}\left(r_{0}\right)=-(T-P) \sum \ln \left(1-\lambda_{t}\right)$ and it is used to test the hypothesis:

$\mathbf{H}_{0}: \operatorname{rank}(\Pi) \leq \mathrm{r} 0$ against $\mathrm{H}_{1}: \operatorname{rank}(\Pi)>\mathrm{rO}(0 \leq \mathrm{r} 0 \leq \mathrm{m}-1)$.

The maximum eigenvalue test statistics is $\mathrm{LR}_{\max }\left(r_{0}\right)=-(T-P) \ln \left(1-\lambda_{r 0+1}\right)$, which can be used to test $\mathbf{H}_{0}: \operatorname{rank}(\Pi)=\mathrm{r} 0$ against $\mathrm{H}_{1}: \operatorname{rank}(\Pi)=\mathrm{rO}+1$. Both the trace and the maximum eigenvalue test statistics have nonstandard asymptotic distributions and thus simulation method is needed to obtain the critical values. The test starts with $r 0=0$ and the value of $\mathrm{r} 0$ gradually increases. The number of cointegration vectors is the value of $\mathrm{r} 0$ when we fail to reject the null hypothesis for the first time (Tsay, 2005).

\section{Granger Causality Test}

Granger Causality is used between two variables in a time series to examine causality. The approach is a probabilistic explanation of causality that can be derived using empirical data 
sets. The strategy is a probabilistic account of causality, making use of empirical facts units to discover association trends. A contrary is a method of "top-down" that assumes that the strategies are now not independent, then the records units are analyzed to see if they are generated independently of each other. Time series must be stationary before analyzing the data using Granger causality. To dispose of the possibility of autocorrelation, facts will be transformed.

For two time series $\mathrm{y} 1$ and $\mathrm{y} 2$, if the variance of the optimum prediction error of $\mathrm{y} 1$ when using all the past values of both $\mathrm{y} 1$ and $\mathrm{y} 2$ is smaller than that when using just the past values of $\mathrm{y} 1$, then it is called that $\mathrm{y} 2$ Granger causes y2, denoted by $\mathrm{y} 2 \Rightarrow \mathrm{y} 2$; if there exists a two direction Granger causality both from $y 1 \Rightarrow y 2$ and from $y 2 \Rightarrow y 1$, then there is a feedback, denoted as y2 $\Rightarrow$ y1 (Granger, 1969).

The hypothesis for the Granger Causality Test are:

$\mathrm{H}_{0}$ : $\mathbf{1} 1$ does not Granger-cause $\mathrm{y} 2$.

$\mathbf{H}_{\mathrm{a}}$ : $\mathbf{y} 2$ does not Granger-cause $\mathbf{1}$

Null hypothesis for this test will be rejected if $p$-value less that 0.05 (or smaller).

\section{Results and Discussion}

This study is using time series where the stationarity of data is crucial for following method, therefore unit root test is employed to check the stationarity of the data series.

Table 1: Augmented Dickey-Fuller (ADF) Unit Root Test Results

\begin{tabular}{lllll}
\hline Series & Level & \multicolumn{3}{c}{ First Difference } \\
\hline & Intercept & $\begin{array}{l}\text { Trend } \\
\text { Intercept }\end{array}$ & Intercept & $\begin{array}{l}\text { Trend } \\
\text { Intercept }\end{array}$ \\
\cline { 2 - 5 } GDPG & $-4.147^{* * *}$ & $-4.805^{* * *}$ & $-5.211^{* * *}$ & $-5.334^{* * *}$ \\
BCR & -0.313 & -2.007 & $-5.040^{* * *}$ & $-4.978^{* * *}$ \\
M & -1.753 & $-2.928^{*}$ & $-7.095^{* * *}$ & $-7.130^{* * *}$ \\
DC & 0.574 & -1.156 & $-4.123^{* * *}$ & $-4.181^{* * *}$ \\
POP & $-3.087^{* *}$ & -1.830 & -1.874 & $-3.345^{*}$ \\
EXP1 & $-3.203^{* *}$ & -3.140 & $-3.347^{* *}$ & $-3.259^{*}$ \\
INF & $-3.750^{* * *}$ & $-4.086^{* * *}$ & $-5.240^{* * *}$ & $-5.016^{* * *}$ \\
\hline
\end{tabular}

Note: Asterisks $(*),\left({ }^{* *}\right)$ and $\left({ }^{* *}\right)$ indicate statistically significant at $10 \%, 5 \%$ and $1 \%$ level, respectively.

Table 1 report the results of the levels and first differences of ADF unit root test. Interestingly, the result of the test for level and first differences is different. Some of the series including BCR, DC, POP, and EXP under consideration are non-stationary in their levels. However, all the series are stationary by using first differences, GDPG, BCR, M, DC, and INF is significant at $1 \%$ while POP and EXP is $10 \%$, Since the above results are significant at the significant level of $1 \%$ and $10 \%$, reject null hypothesis. Thus, we conclude that all the variables are stationary.

Johanson's cointegration approach used to determine the number of cointegrating equations. From the table 2, the Rank Test of (Trace) and (Maximum-Eigenvalue) statistics showed that there is one cointegrating vectors. Therefore, as per the statistics, $\mathrm{H}_{0}$ : 'there is no cointegration' between the variables is rejected at $1 \%$ level of significance, which implies that there is one cointegrating vector between three variables. 
Table 2: Johansen Cointegration Test Results

\begin{tabular}{llllll}
\hline Null & Alternativ & $\mathbf{k}=6 \mathbf{r}=\mathbf{4}$ \\
& e & & & \\
\cline { 3 - 6 } & & $\begin{array}{l}\lambda \text { max } \\
\text { Unadjusted }\end{array}$ & $95 \%$ C.V. & $\begin{array}{l}\text { Trace } \\
\text { Unadjusted }\end{array}$ & 95\% C.V. \\
\cline { 3 - 6 } & & $74.820^{* *}$ & 46.231 & $216.881^{* *}$ & 125.615 \\
$r=0$ & $r=1$ & $42.242^{* *}$ & 40.078 & $142.061^{* *}$ & 95.754 \\
$r \leq 1$ & $r=2$ & $40.227^{* *}$ & 33.877 & $99.819^{* *}$ & 69.819 \\
$r \leq 2$ & $r=3$ & $30.990^{* *}$ & 27.584 & $59.592^{* *}$ & 47.856 \\
$r \leq 3$ & $r=4$ & 17.955 & 21.132 & 28.601 & 29.797 \\
$r \leq 4$ & $r=5$ & 10.438 & 14.265 & 10.647 & 15.495 \\
$r \leq 5$ & $r=6$ & 0.209 & 3.841 & 0.209 & 3.841 \\
$r \leq 6$ & $r=7$ & &
\end{tabular}

Notes: $r$ is the cointegrating vector. Asterisks $\left({ }^{* *}\right)$ indicate significant at $5 \%$ level.

Table 2 demonstrates the Johansen analysis for the co-integration of variables. The trace statistic indicates that one of the factors is cointegrating. Since the trace statistic considers all the smallest self-values, it has more power than the maximum eigenvalue statistic (Kasa, 1992; Serletis \& King, 1997). In addition, Johansen \& Juselius (1990) recommended the use of trace statistics when there is a conflict between the two statistics. This result therefore indicates that there is a long-term correlation between financial development and economic growth.

Table 3: Normalized Cointegrating Vector Test Results

\begin{tabular}{lll}
\hline Cointegrating Eq: & Normalized & [t -statistics] \\
\hline Constant & 257.6847 & \\
GDPG & -1.000 & \\
BCR & -0.331 & {$[9.964]^{* *}$} \\
M & -0.090 & {$[2.319]^{* *}$} \\
DC & 0.099 & {$[-5.668]^{* *}$} \\
POP & 1.829 & {$[-12.944]^{* *}$} \\
EXP1 & 0.624 & {$[-11.388]^{* *}$} \\
INF & -14.250 & {$[16.969]^{* *}$} \\
\hline
\end{tabular}

Note: Asterisks $\left({ }^{* *}\right)$ indicate statistically significant at $5 \%$ level.

Table shown that t-statistics are exceed 1.96, which means all the variables are statistically significant at $5 \%$ level.

The correlation tests the degree to which two factors shift together over time, which has little to do with calculating the "cause and effect" relationship. The causal interaction mechanisms between variables were studied via the Granger causality method. The Granger Causality Test is a predictive prediction check to assess if one-time sequence is effective in forecasting another. Unless the likelihood value is less than every any $\alpha$ level, hypothesis would be rejected. 
Table 4: Granger Causality Test Results

\begin{tabular}{lllll}
\hline $\begin{array}{l}\text { Dependent } \\
\text { Variable }\end{array}$ & $\begin{array}{l}\text { Independent } \\
\text { Variable }\end{array}$ & F-Statistic & p-value & Direction \\
\hline BCR & GDPG & 3.83341 & $0.0359^{* *}$ & Bi-direction \\
GDPG & BCR & 3.20761 & $0.0500^{* *}$ & \\
M & GDPG & 6.58289 & $0.0053^{* * *}$ & Uni-direction \\
GDPG & M & 0.11367 & 0.893 & \\
DC & GDPG & 3.14621 & 0.0612 & No relationship \\
GDPG & DC & 2.41199 & 0.111 & \\
EXP1 & GDPG & 0.12348 & 0.8844 & No relationship \\
GDPG & EXP1 & 0.81213 & 0.4557 & \\
INF & GDPG & 1.74263 & 0.1965 & Uni-direction \\
GDPG & INF & 10.7172 & $0.0005^{* * *}$ & \\
POP & GDPG & 2.03811 & 0.1522 & Uni-direction \\
GDPG & POP & 3.19874 & $0.0587^{* *}$ & \\
\hline
\end{tabular}

Note: Asterisks $\left({ }^{* *}\right)$ and $\left({ }^{* *}\right)$ indicate statistically significant at $5 \%$ and $1 \%$ level respectively.

Table 4 reports the causality test results for financial development and economic growth in China. There is a bidirectional causality between BCR and GDPG based on the Granger tests with the 5\% of significant level. The empirical results show DC and EXP1 has no relationship with GDPG. However, GDPG has a causality relationship from to POP at $5 \%$ significant level; while other are significant at $1 \%$ level of uni-directional causality that is running from $M$ to GDPG and GDPG to INF.

\section{Conclusions}

This study examines the relationship in long run and direction of causality between the financial development and economic growth in China from 1980 to 2018. The empirical results shown there are a co-movement between financial development and economic growth in long run. This means that, in long run, financial development affecting economic growth. The empirical results are supporting the theory finance stimulates economic development a line with previous finding (Dhungana (2016); Goldsmith (1969); King and Levine (1993); Lenka (2015)

Also, the results explain bidirectional relationship between bank credit to the private sector to GDPG. This indicates that the rise in bank credit has a significant causal impact on economic growth. Based on economics theory, higher investment results in higher output, the demand can be boosted in the short term while capital stock can be increased in the long run. The finding explains bank credit has crucial role for capital amounts funding, credit development is an important drive of economic growth as suggested by Musamali et al. (2014); Olowofeso et al. (2015); Prochniak and Wasiak (2017).

Moreover, the finding shown causal direction of economic growth influences financial development. This explains a strong and prosperous economy would contribute to a rise in the financial system. Besides that, control variable also has significant relationship. The empirical results demonstrations unidirectional causality from board money (money supply) growth to GDPG. The changes of money supply affecting the growth of GDP. This finding is consistent with Prochniak and Wasiak (2017), explains that monetization ratio has significant 
impact on economic growth. Inflation and population were shown unidirectional causality to economic growth consistent with Omoke (2010) and Datta and Mukhopadhyay (2011). This means the stability and growing of the economic will cause the price of the goods and the consumption. The higher economic growth rates would clearly lead to higher birth rates and longer ages for senior citizens contributing to population growth.

Lastly, this study also indicates that there was no evidence of causality between GDPG to domestic credit provided by financial sector or government spending, government spending and GDP growth. The findings of this study enrich the empirical evidence on the nexus between financial development and economic growth especially in the context of emerging economies such as China. The results imply financial development fosters economic growth in China; hence, the policy makers should continue to develop the financial structure of the country in order promote the growth of the country.

\section{References}

Al Mamun, M. S., Ariffin, M. I., \& Hamid, Z. (2018). Does Domestic Credit of The Banking Sector Promote Economic Growth? Evidence from Bangladesh. International Journal, 3(1), 3355.

Arrow, K. J., \& Hurwicz, L. (1962). Competitive stability under weak gross substitutability: Nonlinear price adjustment and adaptive expectations. International Economic Review, 3(2), 233-255.

Asteriou, D., \& Spanos, K. (2019). The relationship between financial development and economic growth during the recent crisis: Evidence from the EU. Finance Research Letters, 28, 238-245.

Baier, S. L., Dwyer, G. P., \& Tamura, R. (2003). Does Opening a Stock Exchange Increase Economic Growth? SSRN Electronic Journal.

Calderon, C., \& Liu, L. (2003). The direction of causality between financial development and economic growth. Journal of Development Economics, 72(1), 321-334.

Datta, K., \& Mukhopadhyay, C. K. (2011). Relationship between inflation and economic growth in Malaysia-An econometric review. International Conference on Economics and Finance Research, 4(1), 415-419.

De Gregorio, J., \& Guidotti, P. E. (1995). Financial development and economic growth. World Development, 23(3), 433-448.

Dhungana, B. R. (2016). Does Financial Institution Support for Economic Growth? A Case of Nepal. Economic Literature, 12, 56.

Eryılmaz, F., Bakır, H., \& Mercan, M. (2015). Financial Development and Economic Growth: Panel Data Analysis. In Handbook of Research on Strategic Developments and Regulatory Practice in Global Finance (pp. 233-245). IGI Global.

Gokal, V., \& Hanif, S. (2004). Relationship between Inflation and Economic Growth. Economics Department. Reserve Bank of Fiji. Fiji. Working Paper: 2004/04.

Goldsmith, R. W. (1969). Financial structure and development.

Granger, C. (1969). Investigating Causal Relations by Econometric Models and Cross-Spectral Methods. Econometrica, 37(3), 424-438.

Howitt, P., \& Aghion, P. (1998). Capital accumulation and innovation as complementary factors in long-run growth. Journal of Economic Growth, 3(2), 111-130.

Johansen, S. (1988). Statistical analysis of cointegration vectors. Journal of Economic Dynamics and Control, 12(2-3), 231-254. 
Johansen, S. (1991). Estimation and Hypothesis Testing of Cointegration Vectors in Gaussian Vector Autoregressive Models. Econometrica, 59(6), 1551-1580.

Johansen, S., \& Juselius, K. (1990). Maximum Likelihood Estimation and Inference on Cointegration-With Applications to the Demand for Money. Oxford Bulletin of Economics and Statistics, 52(2), 169-210.

Karlsson, H., \& Mansson, K. (2015). Revisiting the nexus of the financial Development and economic growth-Wavelet approach with a focus on Asian economies. Research Network Debate, Swedish Entrepreneurship Forum, Stockholm.

Kasa, K. (1992). Common stochastic trends in international stock markets. Journal of Monetary Economics, 29(1), 95-124.

King, R. G., \& Levine, R. (1993). Finance and growth: Schumpeter might be right. The Quarterly Journal of Economics, 108(3), 717-737.

Kyophilavong, P., Uddin, G. S., \& Shahbaz, M. (2016). The Nexus between Financial Development and Economic Growth in Lao PDR. Global Business Review, 17(2), 303317.

Lenka, S. K. (2015). Does Financial Development Influence Economic Growth in India? Theoretical \& Applied Economics, 22(4).

Levine, R. (2004). Finance and Growth: Theory and Evidence (Working Paper No. 10766; Working Paper Series). National Bureau of Economic Research.

Lucchetti, R. (Jack), Papi, L., \& Zazzaro, A. (2001). Banks' Inefficiency and Economic Growth A Micro-Macro Approach (Development Working Papers No. 153). Centro Studi Luca d'Agliano, University of Milano.

Mallick, H., \& Agarwal, S. (2007). Impact of Real Interest Rates On Real Output Growth In India: A Long-Run Analysis In A Liberalized Financial Regime. The Singapore Economic Review, 52(02), 215-231.

Mishkin, F. S. (2007). Inflation dynamics. International Finance, 10(3), 317-334.

Musamali, R. A., Nyamongo, E. M., \& Moyi, E. D. (2014). The relationship between financial development and economic growth in Africa. Research in Applied Economics, 6(2), 190208.

Naughton, B. (2007). The Chinese economy: Transitions and growth. MIT Press.

Olowofeso, E. O., Adeleke, A. O., \& Udoji, A. O. (2015). Impact of private sector credit on economic growth in Nigeria. CBN Journal of Applied Statistics, 6(2), 81-101.

Omoke, P. C. (2010). Inflation and Economic Growth in Nigeria. Journal of Sustainable Development, 3(2), p159.

Prochniak, M., \& Wasiak, K. (2017). The impact of the financial system on economic growth in the context of the global crisis: Empirical evidence for the EU and OECD countries. Empirica, 44(2), 295-337.

Schumpeter, J. A. (1912). Theory of Economic Development. Routledge.

Serletis, A., \& King, M. (1997). Common Stochastic Trends and Convergence of European Union Stock Markets. The Manchester School of Economic \& Social Studies, 65(1), 4457.

Shahbaz, M., Hye, Q. M. A., Tiwari, A. K., \& Leitão, N. C. (2013). Economic growth, energy consumption, financial development, international trade and $\mathrm{CO} 2$ emissions in Indonesia. Renewable and Sustainable Energy Reviews, 25, 109-121.

Shaw, E. (1973). Financial Deepening in Economic Development. New York: Oxford University Press. 
INTERNATIONAL JOURNAL OF ACADEMIC RESEARCH IN BUSINESS AND SOCIAL SCIENCES Vol. 11, No. 5, 2021, E-ISSN: 2222-6990 @ 2021 HRMARS

Solow, R. M. (1956). A Contribution to the Theory of Economic Growth. The Quarterly Journal of Economics, 70(1), 65.

Tsay, R. S. (2005). Analysis of Financial Time Series: Analysis of Financial Time Series. John Wiley \& Sons, Inc.

World Bank Open Data. (2019). (The World Bank Group) Retrieved from https://data.worldbank.org/

Yueh, L. (2013). What drives China's growth? National Institute Economic Review, 223(1), R4R15. 